\title{
Occupational low back pain in nursing workers: massage versus pain*
}

\author{
LOMBALGIA OCUPACIONAL EM TRABALHADORES DE ENFERMAGEM: MASSAGEM \\ VERSUS DOR
}

\section{LUMBALGIA OCUPACIONAL EN TRABAJADORES DE ENFERMERÍA: MASAJE VERSUS DOLOR}

\author{
Talita Pavarini Borges ${ }^{1}$, Leonice Fumiko Sato Kurebayashi², Maria Júlia Paes da Silva ${ }^{3}$
}

\begin{abstract}
Objective: To assess the efficacy of massage for decreasing occupational low back pain in workers of a Nursing team in an Emergency Room. Method: A randomized controlled trial, using a socio-demographic/morbidity questionnaire and a Pain Numeric Scale. Forty-five subjects were randomly allocated for intervention (G1 Massage by acupressure), placebo group (G2 - application of Garlium Arseneid Laser $904 \mathrm{~nm}$ turned off) and control (G3 - no intervention). Results: The main triggering factor, as well as the worsening of pain, was the patient manipulation, both with a prevalence of $34.9 \%$. The main treatment for low back pain before this research was the use of medication, with a prevalence of $44.2 \%$. In accordance with a variance analysis, only G1 presented a significant statistical difference, with a better result after 12 sessions. Massage presented an enormous effect $(d=4.59$ ), corresponding to $86 \%$ of reduction in the pain level. Conclusion: Massage was effective to decrease occupational low back pain of those Nursing workers.
\end{abstract}

\section{DESCRIPTORS \\ Massage \\ Low back pain \\ Complementary therapies \\ Nursing \\ Occupational health}

\begin{abstract}
RESUMO
Objetivo: Avaliar a eficácia da massagem para diminuição de lombalgia ocupacional em trabalhadores da equipe de Enfermagem de um Pronto-Socorro. Método: Ensaio clínico randomizado, com utilização do Questionário sociodemográfico/morbidade e Escala Numérica de Dor. Foram randomizados 45 sujeitos aleatoriamente em grupo intervenção (G1-Massagem por acupressão), grupo placebo (G2 - aplicação do Laser Arseneto de Gálio $904 \mathrm{~nm}$ desligado) e controle (G3-sem intervenção). Resultados: O principal fator desencadeante, como também de piora da lombalgia, foi a manipulação do paciente, ambos com $34,9 \%$ de prevalência. 0 principal tratamento anterior à pesquisa para lombalgia foi o uso de medicações, com $44,2 \%$. Segundo Análise de Variância, somente o G1, conseguiu diferença estatística significativa, com melhor resultado após 12 sessões. A massagem conseguiu um efeito enorme $(d=4,59)$, correspondente a $86 \%$ de redução dos níveis de dor. Conclusão: A massagem foi eficaz para diminuir a lombalgia ocupacional desses trabalhadores de Enfermagem.
\end{abstract}

\author{
DESCRITORES \\ Massagem \\ Dor lombar \\ Terapias complementares \\ Enfermagem \\ Saúde do trabalhador
}

\section{RESUMEN}

Objetivo: Evaluar la eficacia del masaje para la reducción de la lumbalgia ocupacional en trabajadores del equipo de enfermería. Método: Ensayo clínico randomizado, en el cual se utilizaron el Cuestionario sociodemográfico/morbilidad y la escala numérica de dolor. Se distribuyeron aleatoriamente 45 sujetos en: grupo intervenido (G1-Masaje por acupresión), grupo placebo (G2-aplicación de Laser Arseniuro de Galio $904 \mathrm{~nm}$ apagado) y grupo control (G3-sin intervención). Resultados: El principal factor desencadenante, así como del empeoramiento del dolor fue la manipulación del paciente, ambos con $34,9 \%$ de prevalencia. El principal tratamiento para la lumbalgia antes del estudio fue el uso de fármacos en el $44,2 \%$ de los participantes. Según el análisis de la varianza, sólo el G1 logró una diferencia estadísticamente significativa, con mejores resultados después de 12 sesiones. El masaje obtuvo un efecto enorme $(d=4,59)$, correspondiente a la reducción del $86 \%$ en los niveles del dolor. Conclusión: El masaje fue efectivo para reducir el dolor de espalda de estos trabajadores de enfermería.

\section{DESCRIPTORES \\ Masaje \\ Dolor de la región lumbar \\ Terapias complementarias \\ Enfermería \\ Salud laboral}

"Extracted from the dissertation "Uso da massagem como intervenção na lombalgia ocupacional em Trabalhadores de enfermagem", Nursing School, Universidade de São Paulo, 2013. ${ }^{1}$ Master of Sciences, School of Nursing, University of São Paulo, São Paulo, SP, Brazil. ${ }^{2}$ PhD of Sciences, School of Nursing, University of São Paulo, São Paulo, SP, Brazil. ${ }^{3}$ Full Professor, Department of Medical Surgical Nursing, School of Nursing, University of São Paulo, São Paulo, SP, Brazil.

$\begin{aligned} \text { Rev Esc Enferm USP } & \text { Received: } 12 / 12 / 2013 \\ 2014 ; 48(4): 670-6 & \text { Approved: } 04 / 16 / 2014 \\ \text { www.ee.usp.br/reeusp/ } & \end{aligned}$




\section{INTRODUCTION}

Labor back pain has been highly prevalent and it is a musculoskeletal disorder that directly interferes in the quality of life at work and overloads the health system due to the high index of absenteeism and removals attributed to $i^{(1)}$. The main related reason as triggering factor for low back pain is the unbalance between the needed effort to perform an activity and the potential to perform it, that is, an unbalance between the functional load and the functional capacity ${ }^{(2)}$.

National and international researchers reveal that due to the profession characteristics, as well as the work conditions, the Nursing team presents a high probability to develop low back pain ${ }^{(3-5)}$ and consequently it negatively impacts the quality of assistance offered to the population. Researchers reveal that Nursing presents a low back pain prevalence with expressive values, as in a study where it reached $71.5 \%$ of the team ${ }^{(6)}$, and in other, $80 \%$ of professionals ${ }^{(5)}$.

There are different treatments for low back pain, pharmacological and non-pharmacological ones. Within the non-pharmacological possibilities, massage represents an alternative with benefits specially related to pain $^{(7)}$ and wellbeing promotion ${ }^{(8)}$.

\section{Massage can be defined as}

a conjunct of manipulations on the soft tissues of the body. Those manipulations can be done with the hands and they are administered with the finality to produce effects on the nervous, muscular and respiratory system, and in the local and general blood and lymph circulation ${ }^{(9)}$.

Regarding the ethical and legal aspects, massage is part of Natural Therapies, as denominated by the Municipal Law of São Paulo no 13.717 , since $2004^{(10)}$. This Law supports the use of massage to attend the population through the Brazilian Unified Health System. The nurse is a health professional who could apply this practice, constituting it as one of its therapeutic possibilities, in accordance with the Resolution $\mathrm{n}$ - $197 / 1997^{(11)}$ of the Nursing Federal Council.

Considering the previous information, the objective of this research was to assess the efficacy of massage application after the work shift to reduce occupational low back pain in a Nursing team, aiming to prove the hypothesis that massage decreases the pain score from moderate to low, as well as to identify improvement and worsening factors for the algic framework of this team.

\section{METHOD}

This is a randomized controlled trial, with three groups: G1 or GM (massage by acupressure), G2 or GP (application of the Garlium Arseneid Laser 904nm turned off) and G3 or control (answers to a questionnaire and with no intervention). The research was developed in an Emergency Room COHAB II (ER), in the city of Carapicuíba, São Paulo State. The study attended to the Resolution no 196/1996 of the Brazilian Health National Council, it was accepted by the Ethics in Research Committee of the Nursing School from the Universidade Federal de São Paulo (Protocol CEP-EEUSP no 20328) and it was authorized by the Unit Clinical Director for its execution. After explanation, the Free and Informed Consent Term was signed by all who wished to participate, and the participants were guaranteed that they in case they were randomized in group G2 (GP) or in G3 (control), after the study, they could be attended with massage sessions during the same period of time, with no cost. It was also guaranteed that, for the G1 (GM), in case of pain worsening due to the intervention, those would receive sessions of physical therapy with no cost. Pre-established protocols were applied to G1 (GM) and G2 (GP) for 20 minutes, two times per week, during 6 weeks, totalizing 12 sessions, applied by a nurse, responsible researcher.

The definition of a convenience sample was due to the invitation designed for all workers of the ER Nursing team (nurses, technicians and nursing assistants), who belong to day and night shifts and perform 12 to 36 hours work journeys. Posteriorly, after the inclusion and exclusion criteria were met, they were randomized, by a computer program - Research Randomizer - in the groups G1 (GM), G2 (GP) or G3 (control).

The inclusion criteria were: (1) Employees from both genders with time availability for the sessions; (2) To present self-reported low back pain or identified by medical diagnosis; (3) Individuals with a score four to seven in the Pain Numerical Scale.

The exclusion criteria were: (1) To be pregnant; (2) To go on vacations or medical license during the study period; (3) To present spondylolisthesis, herniated discs and self-reported lumbar sciatic pain or found by medical diagnosis; (4) To use anti-inflammatory medication, analgesics up to seven days before the study beginning and during the 12 massage sessions; (5) To be in treatment for low back pain with complimentary practices, as massage, acupuncture, auriculotherapy; (6) To have open areas, for example, wounds or burns in any part of the back or buttocks; (7) To have skin cancer; (8) To have severe infections in any part of the back or buttocks; (9) To have acute or chronic cutaneous conditions in any part of the back or buttocks, as psoriasis or dermatitis; (10) To have extended edema in any part of the back or buttocks; (11) To have received radiotherapy in any part of the back or buttocks three to six months before.

The data were collected between August and October of 2012 and the appointments were done in a private room in the ER. The following assessment instruments were used for all participants: Pain Estimated Numeric Scale ${ }^{(12)}$, Sociodemographic Data and Morbidity Questionnaire. The Pain Numeric Visual Scale ${ }^{(12)}$ was applied in the session 1, before 
the intervention and the placebo and repeated in the $6^{\text {th }}$ and $12^{\text {th }}$ session. For the $\mathrm{G} 3$, the $\mathrm{G} 1$ sessions were used as a time parameter. The pre-established protocols were described and used for the $\mathrm{G} 1$ and $\mathrm{G} 2$, and applied by the nurse:

\section{Massage Group Protocol - G1 or GM}

The protocol used in this project was exactly the same as the one from a project developed in $2012^{(5)}$. The subjects were positioned in a stretcher in horizontal ventral decubitus. The technique applied was the acupressure in the points visualized in Figure 1. Smoothing, pressure and kneading were used. This group was denominated G1 or GM.

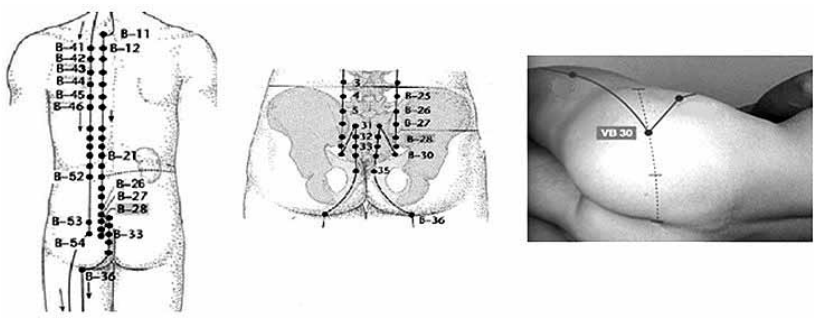

Figure 1 - Modified points image from the protocol - São Paulo, $2010^{(5)}$.

\section{Placebo Group Protocol - G2 or GP}

The Group G2 received Garlium Arseneid Laser 904nm application, on the same established points of the massage protocol (Figure 1), at a 0.5 to $1 \mathrm{~cm}$ distance from the skin, for 0.2 seconds approximately in each point, with the participants also laying in a stretcher in a horizontal ventral decubitus. The device was used turned off in all sessions, but with no previous knowledge from the individuals.

\section{Control Group Protocol - G3}

This group received no intervention, only answering to the evaluation tools.

\section{Data treatment}

For quantitative variables it was used means parameters, standard deviation; for qualitative variables, absolute and relative frequencies were calculated.

The socio-demographic variables evaluated at the beginning were compared between groups, with Analysis of Variance for quantitative variables: age, Body Mass Index (BMI), weight and height.

The association within the qualitative variables (gender, marital status, ways of transportation, actual position, existence of an underlying disease, previous treatment for low back pain, removal time) and with the Groups were assessed with a Chi-Square test.

In order to verify differences within the Numerical Estimative Pain Scale mean, models were presented considering the structure of the answers correlation over time with the Analysis of Variance for repetitive measures.
The dimension of effect was also verified calculating the Cohen $\mathrm{d}$ test for the data collected with the Pain Numerical Scale.

\section{RESULTS}

The initial sample was composed by 45 workers from the Nursing team, corresponding to $66.2 \%$ of a total of 68 workers from the ER COHAB II, equally divided in three groups. Six nurses, 20 technicians and 17 nursing assistants participated. There were two losses during the study due to the use of anti-inflammatory medication; one in the $\mathrm{G} 1$ (GM) and the other in the G3 (control), finalizing a sample of 43 workers divided as G1 (14), G2 (15), and G3 (14).

Females were predominant, composing $76.7 \%$ of the sample. The participants presented a mean BMI of 27.8 (SD 4.4), corresponding to overweight category, in accordance with the World Health Organization (WHO), for both genders. The mean age was 39.6 years (SD 9.6), with 25 years as minimum and 61 years as maximum. The mean work time in that ER was 3.8 years and none of them received labor training related to the manipulation of weight or patients. The mean of removal days due to low back pain was 2.4 .

The socio-demographic characteristics of the sample are found in Table 1.

After the application of the Chi-Square test, the only variable that presented a significant $p$ value was the work shift, even with the sample randomization.

There was a significant, although weak, positive correlation between the work time in the unit and the time of back pain with $\mathrm{p}=0.02$ and $\mathrm{rho}=0.347$.

When questioned about the recurrent treatments for low back pain alleviation, the exclusive use of medication was highlighted in $44.2 \%$ of the sample, followed by the treatment medication + association (25.4\%) referring to the combination of medication with physical therapy, massage, Global Posture Re-education (RPG), stretching, walking and acquisition of orthopedic mattress. Regarding Natural Therapies, the most searched ones were: acupuncture (11.5\%), massage (4.7\%) and the association of those (4.7\%).

The perceived time of low back pain had an average of 4.4 years. The type of pain with burning sensation was highlighted in 23 (54.8\%) of subjects, followed by the sting sensation (23.8\%). The duration had higher values in the intermittent classification with 22 subjects (51.2\%).

Only a part of the sample $(46.5 \%)$ could punctuate the beginning of the pain, with emphasis on the beginning of career, correspondent to ten subjects (23.3\%). Thirty-six subjects ( $83.7 \%$ of the sample) reported pain exclusive on 'the low back region. The others added discomfort on the low back region to the cervical and thoracic region and one person also punctuated pain on the right shoulder. 
Table 1 - Distribution of occupation, work shift, marital status, number of children and presence of underlying disease by group, from the sample of subjects of the Emergency Room COHAB II - Carapicuíba, SP, Brazil, 2012

\begin{tabular}{|c|c|c|c|c|c|c|c|c|c|c|}
\hline \multirow{2}{*}{ Variable } & \multirow{2}{*}{ Factor } & \multicolumn{2}{|c|}{ Massage $(n=14)$} & \multicolumn{2}{|c|}{$\operatorname{Laser}(n=15) *$} & \multicolumn{2}{|c|}{ Control $(n=14)$} & \multicolumn{2}{|c|}{ Total $(n=43)$} & \multirow{2}{*}{ p value } \\
\hline & & $\mathbf{N}$ & $\%$ & $\mathbf{N}$ & $\%$ & $\mathbf{N}$ & $\%$ & $\mathbf{N}$ & $\%$ & \\
\hline \multirow{3}{*}{ Position } & Assistant & 5 & 35.7 & 7 & 46.6 & 5 & 35.7 & 17 & 39.5 & \multirow{3}{*}{0.826} \\
\hline & Nurse & 2 & 14.3 & 1 & 6.7 & 3 & 21.4 & 6 & 14 & \\
\hline & Technician & 7 & 50 & 7 & 46.7 & 6 & 42.9 & 20 & 46.5 & \\
\hline \multirow{2}{*}{ Work Shift } & Night & 8 & 57.1 & 2 & 13.3 & 11 & 78.6 & 21 & 48.8 & \multirow{2}{*}{0.002} \\
\hline & Day & 6 & 42.9 & 13 & 86.7 & 3 & 21.4 & 22 & 51.2 & \\
\hline \multirow{2}{*}{ Gender } & Male & 1 & 7.1 & 4 & 26.7 & 5 & 35.7 & 10 & 23.3 & \multirow{2}{*}{0.187} \\
\hline & Female & 13 & 92.9 & 11 & 73.3 & 9 & 64.3 & 33 & 76.7 & \\
\hline \multirow{4}{*}{$\begin{array}{l}\text { Martial } \\
\text { Status }\end{array}$} & Married & 9 & 64.3 & 8 & 53.3 & 7 & 50 & 24 & 55.8 & \multirow{4}{*}{0.69} \\
\hline & Divorced & 0 & 0 & 0 & 0 & 1 & 7.1 & 1 & 2.3 & \\
\hline & Single & 4 & 28.6 & 6 & 40 & 6 & 42.9 & 16 & 37.2 & \\
\hline & Widow & 1 & 7.1 & 1 & 6.7 & 0 & 0 & 2 & 4.7 & \\
\hline \multirow{5}{*}{ Children } & 0 & 4 & 28.6 & 5 & 33.3 & 5 & 35.8 & 14 & 32.5 & \multirow{5}{*}{0.77} \\
\hline & 1 & 2 & 14.3 & 6 & 40 & 4 & 28.6 & 12 & 27.9 & \\
\hline & 2 & 4 & 28.6 & 3 & 20 & 3 & 21.4 & 10 & 23.3 & \\
\hline & 3 & 1 & 7.1 & 0 & 0 & 1 & 7.1 & 2 & 4.7 & \\
\hline & 4 & 3 & 21.4 & 1 & 6.7 & 1 & 7.1 & 5 & 11.6 & \\
\hline \multirow{2}{*}{$\begin{array}{l}\text { Underlying } \\
\text { disease }\end{array}$} & Yes & 4 & 28.6 & 3 & 20 & 1 & 7.1 & 8 & 18.6 & \multirow{2}{*}{0.341} \\
\hline & No & 10 & 71.4 & 12 & 80 & 13 & 92.9 & 35 & 81.4 & \\
\hline
\end{tabular}

${ }^{\star}$ Placebo Group

Participants were asked about labor factors triggering the pain. Manipulation of patients (decubitus change, transferring patients in chairs, bed or stretcher) corresponded to $34.9 \%$. To lift weights and to do procedures like venous puncture, catheterizations and bed baths stayed with 9.3\% each. Also, $7 \%$ answered to the action of lowering and raising with frequency, to restrain patients (workers from the psychiatric sector) and standing up for long periods of time, both with $4.7 \%$ and to push the stretcher, with 2.3 .

Within the improvement factors, $32.6 \%$ were strictly pharmacological strategies; $23.3 \%$ were mixed strategies, that is, medications associated with shower, massages and rest. In the non-pharmacological measures, the use of heat was recurrent in the following activities: shower $(9.3 \%)$, local heating and movements $(2.3 \%$ and $7 \%$, respectively). The use of massage appeared also associated with shower and rest (4.7\%).

As worsening factors, there was emphasis again to manipulation of patients with $34.9 \%$ followed by realization of procedures and lifting weight with $11.6 \%$, to stand up for long periods of time and lowering and standing with 9.3\%, restraining psychiatric patients and low ambient temperatures with 7\%; transportation of patients and sitting down for long periods of time with $4.7 \%$. Table 2 illustrated the distribution of pain intensity in the beginning of the study.

The data referred to pain in the groups GM or G1 were compared to $\mathrm{G} 2$ and $\mathrm{G} 3$ or control.

It is observed that, even counting with the simple randomization propitiated by the computer program, the G1 or GM initiated the study with a higher intensity of pain, inside a same level of pain, in comparison with the other groups. Therefore, as a group, in the beginning of data collection, the G1 or GM presented the worse pattern for pain, and in the control group were the people with less intense levels of pain.

Table 2 - Distribution of subjects, by pain intensity, in the first evaluation by group - Carapicuíba, SP, Brazil, 2012

\begin{tabular}{cccccccccc}
\hline \multirow{2}{*}{$\begin{array}{c}\text { Pain } \\
\text { Intensity }\end{array}$} & \multicolumn{2}{c}{$\begin{array}{c}\text { Massage } \\
(\mathrm{n}=14)\end{array}$} & \multicolumn{2}{c}{$\begin{array}{c}\text { Laser } \\
(\mathrm{n}=15)^{*}\end{array}$} & Control $(\mathrm{n}=14)$ & \multicolumn{2}{c}{$\begin{array}{c}\text { Total } \\
(\mathrm{n}=43)\end{array}$} \\
\cline { 2 - 10 } & $\mathrm{N}$ & $\%$ & $\mathrm{~N}$ & $\%$ & $\mathrm{~N}$ & $\%$ & $\mathrm{~N}$ & $\%$ \\
\hline 4 & 0 & 0 & 2 & 13.3 & 7 & 50.1 & 9 & 20.9 \\
5 & 3 & 21.4 & 5 & 33.3 & 3 & 21.4 & 11 & 25.6 \\
6 & 2 & 14.3 & 4 & 26.7 & 1 & 7.1 & 7 & 16.3 \\
7 & 9 & 64.3 & 4 & 26.7 & 3 & 21.4 & 16 & 37.2 \\
\hline Total & 14 & 100 & 15 & 100 & 14 & 100 & 43 & 100 \\
\hline
\end{tabular}

*Placebo Group

X-squared $=15.4271, \mathrm{df}=6, \mathrm{p}$-value $=0.01718$

In Figure 2, the behavior of the pain intensity in the three evaluation moments are observed. The massage group obtained an abrupt decrease in pain scores on the first to the second evaluation $(6.4-3.4 / p<0.001)$. The drop in scores had continuity, but from the second to the third evaluation the drop was less intense (3.4 - 0.9/ $\mathrm{p}<0.001)$. In the laser group there was also a decrease, however, it was more subtle between the first and the second evaluation (5.7-4.8/ p>0.05), with a discrete continuity of drop until the $3^{\text {rd }}$ evaluation, but not significant (4.8 - 4.7 / $p>0.05)$. The control group, although started with an average pain intensity lower than the other groups, had an increase in its values between the evaluations $(5.0-5.3-5.9 / p>0.05)$. 


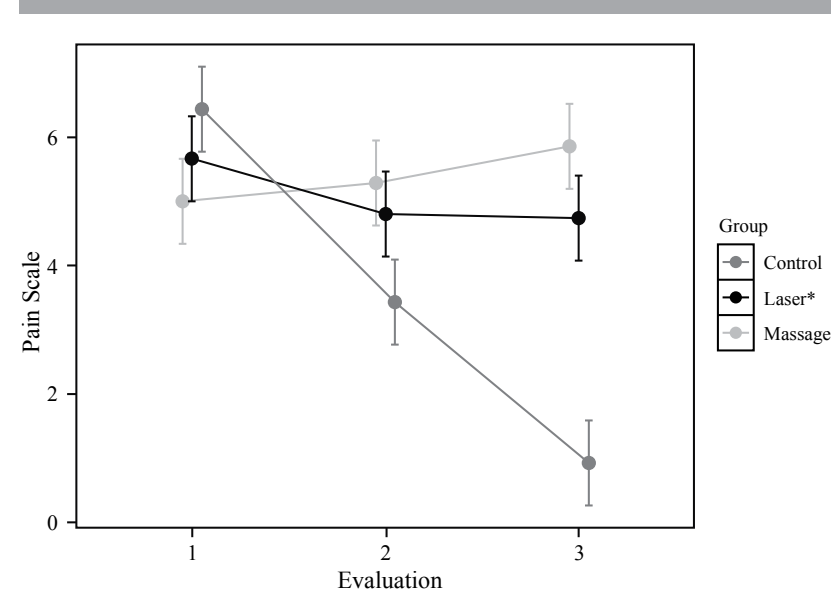

*Placebo Group

Figure 2 - Evolution of pain scores, following the moment of assessment - Carapicuíba, SP Brazil, 2012.

The effect size, exposed by the d-Cohen test, was applied to the three groups, propitiating the following results: in G1 or GM there an enormous effect size between evaluations, with emphasis to the percentage $86 \%$ of reduction in the pain score between the third and first evaluation. The G2 (GP) obtained a $17 \%$ effect (medium decrease) between the third and first evaluation. In the G3 (control) the pain behavior is observed in an inversed pattern in comparison to $\mathrm{G} 1$ and $\mathrm{G} 2$, as there was increase in the pain score, reaching $17 \%$ in the same evaluation moment, that is, between the third and first evaluation.

Regarding the tolerability to treatment, it was possible to observe that all subjects of the massage group reported discomfort on the gallbladder point 30 until the last session. Other points that initially caused high discomfort were the points B23 until B28. Thus, they presented decrease in discomfort more rapidly, on the $6^{\text {th }}$ session there were no more reports.

\section{DISCUSSION}

In this study, women represented $76.7 \%$, showing the prevalence of females within the Nursing profession, have been still current and persistent. In fact, in 2011, the COFEN published a report with a data analysis of existing nursing professionals in the Regional Councils ${ }^{(13)}$ and the percentage of females in the profession, in a national level, was $87.2 \%$, and in São Paulo State, $86 \%$.

The participating workers form the ER demonstrated to be overweight in comparison to the ideal weight, in accordance with the BMI calculation. This reality is verified in workers from diverse regions of Brazil and worldwide $^{(14)}$ and it is really worrying due to the correlation of overweight with cardiovascular diseases (specially heart diseases and stroke), diabetes, musculoskeletal disorders (specially osteoarthritis), few types of cancer (endometrium, breast and colon) ${ }^{(15)}$, associated with a profession which deals with stress ${ }^{(16)}$.
In this study, the average of removal days in 2012 was 2,4 days. It is important to note that low back pain has been the first cause of absenteeism in work in the economically active age group ${ }^{(17)}$.

Regarding medications, it was used as dealing strategies in $69.6 \%$ of subjects, with exclusive use $(44.2 \%)$ or associated to non-pharmacological measures (25.4\%). These data suggest a possible limitation of the treatment exclusively pharmacological for those conditions, as described in a meta-analysis about chronic low back pain ${ }^{(18)}$ and the importance of techniques association, especially when it is chronic. On the other hand, massage showed relevant results in the actual study as only treatment, although it is recommended as an adjuvant part in the treatment of musculoskeletal pain. A systematic review with metaanalysis ${ }^{(19)}$ verified that massage presented a significant improvement in pain compared to no treatment or placebo for low back and neck pain.

Related to pain characterization, the mean time of perception in this study was 4.4 years, indicating chronicity. The perception of the beginning of pain in Nursing workers was related to the beginning in their career. Another study found that the beginning of pain was during their bachelor degree period, with its intensification at the beginning of professional life due to loads and ergonomic matters in the assistance to patients ${ }^{(20)}$.

The occurrence of low back pain in the Nursing team has been constant. Nurses from the Centro Hospitalar Tondela-Viseu, from Portugal, presented a low back pain prevalence of $78.6 \%$ on the last 12 months, referred to $2011^{(21)}$. In Brazil, the prevalence of this disorder varies from 43 to $93 \%{ }^{(22)}$.

Manipulation of patients was configured as one of the triggering factors for low back pain, as well as one of the causes for pain severity. The types of activities developed by the Nursing team in the hospital environment exposes them to physical, chemical, biological, psychosocial and ergonomic risks ${ }^{(3)}$. In the literature, a high diversity of causing factors have been pointed, as: organization at work, duration of cycles, existence of pauses and time structure ${ }^{(22)}$, repetition of movements, to lift weights, to push heavy objects, posture involving tasks with trunk rotation and flexion, to sit for long periods of time ${ }^{(17,22)}$, to gain weight, obesity, bad posture, height, weakness of abdominal muscles, lack of physical fitness ${ }^{(22)}$, as well as the discontent and demotivation with the labor activity ${ }^{(17)}$.

Another study conducted in a public hospital in the interior of São Paulo, of secondary level, identified the sectors with higher number of removals of nursing workers, with emphasis to the adult emergency-room, followed by the adult intensive therapy unit and the surgical center. As well as the musculoskeletal disorders as the main reasons for removal(23). 
The massage efficacy in the present study was also validated by the utilization of the Cohen's $d$ test, that presented a $d$ index of 4.49 (enormous effect) and $86 \%$ of pain reduction. When comparing two different types of procedures for low back pain treatment from the $d$ index and the percentage of changes, before and after treatment, it was found that acupuncture, performed in 130 individuals with non-specific back pain, after 12 sessions, two times per week, per six weeks, reached important positive results ( $d=1.86)$, corresponding to $55 \%$ of improvement ${ }^{(24)}$. And still, regarding the other treatments, the use of transdermal opioid buprenorphine analgesic medication for chronic moderate and severe low back pain reached a side effect of $26 \%(\mathrm{~d}=0.86)$, for 50 individuals $^{(25)}$. Those two last studies were clinical trials with a placebo group.

Finally, the best size effect found for the low back pain treatment came from the association of techniques. In a randomized clinical trial(3), single blind, conducted with nurses with chronic low back pain compared two groups: the intervention group received information about ergonomics, muscle strengthening and stretching. The control group received passive physical therapy composed by the application of TENS (transcutaneous electrical nerve stimulation), application of local heat by thermal bags in their residence, Swedish massage, ultrasound and osteokinematic passive mobilization. In both groups there was reduction in pain intensity, with a 8.25 Cohen index in the intervention group and 8.19 in the control group and an effect size of $90 \%$ and $88 \%$, respectively.

Although, to be able to affirm that the results found with the massage are equally comparable or better than other techniques in the treatment for low back pain, more studies would be needed, with an increased sample and

\section{REFERENCES}

1. Borges TP, Greve JMDA, Monteiro AP, Silva RES, Giovani AMM, Silva MJP. Massage application for occupational low back pain in nursing staff. Rev Latino Am Enferm. 2012;20(3):511-9.

2. Lizier DT, Perez MV, Sakata RK. Exercises for nonspecific low back pain treatment. Rev Bras Anestesiol. 2012;62(6):842-6.

3. Jaromi M, Nemeth A, Kranicz J, Laczko T, Betlehem J. Treatment and ergonomics training of work-related lower back pain and body posture problems for nurses. J Clin Nurs. 2012;21(11-12):1776-84.

4. Ribeiro RP, Martins JT, Marziale MHP, Robazzi MLCC. Workrelated illness in nursing: an integrative review. Rev Esc Enferm USP. 2012;46(2):495-504. with multicenter studies. It is important to note that finding a placebo group for a study is also a big challenge, because the touch, even when subtle, stimulates mechanic receptors, resulting in activity on the tissue region and consequently stimulating the somatic sensorial cortex and the limbic system ${ }^{(26)}$. Studies ${ }^{(27-28)}$ involving massage use turned off devices as alternatives to placebo. Thus, new designs would be needed for future studies.

The findings from this study, however, are promising, because interventions offering a holistic, whole, less invasive and effective care have been proposed and encouraged as needed to support in coping and in reducing the health risk for workers, promoting comfort and benefits to those who receive $i^{(29-30)}$.

\section{CONCLUSION}

Massage was proven as a complementary effective therapy to decrease occupational low back pain in Nursing workers, improving pain scores and altering pain from moderate to low. The obtained results were relevant to broad the knowledge about massage, to recognize triggering factors for labor low back pain and to consider massage as a possible future therapy for nurses, for the benefit and comfort of patients, as a well-cared and painfree professional can better contribute and do their tasks. The study limitations were the reduced number of subjects and the difficulty to choose a placebo group for massage. This way, it is suggested to conduct more studies aiming to confirm the findings of the present study.

5. Santos Júnior BJ, Silveira CLS, Araújo EC. Condições de trabalho e a ergonomia como fatores de risco à saúde da equipe de Enfermagem do Serviço de Atendimento Móvel de Urgência SAMU/Recife-PE. Rev Enferm UFPE On Line [Internet]. 2010 [citado 2012 maio 10];4(1):245-53. Disponível em: http:// www.revista.ufpe.br/revistaenfermagem/index.php/revista

6. Magnago TSBS, Lisboa MT, Griep RH, Kirchhof AL, Guido, LA. Psychosocial aspects of work and musculoskeletal disorders in nursing workers. Rev Latino Am Enferm. 2010;18(3):429-35.

7. Last AR, Hulbert K. Chronic low back pain: evaluation and management. Am Fam Pshysician. 2009;79(12):1067-74.

8. Furlan AD, Imamura M, Dryden T, Irvin E. Massage for low back pain: an updated systematic review within the framework of the Cochrane Back Review Group. Spine. 2009;34(16):1669-84. 
9. De Domenico G. Técnicas de massagem de Beard: princípios e práticas da manipulação de tecidos moles. Rio de Janeiro: Elsevier; 2008.

10. São Paulo (Cidade). Lei n. 13.717, de 08 de janeiro de 2004. Dispõe sobre a implantação das Terapias Naturais na Secretaria Municipal de Saúde [Internet].São Paulo; 2004. [citado 2011 nov. 01]. Disponível em: http://www3.prefeitura.sp.gov.br/cadlem/ secretarias/negocios juridicos/cadlem/integra.asp?alt=09012004L\%20 137170000

11. Conselho Federal de Enfermagem (COFEN). Resolução COFEN-197/1997. Estabelece e reconhece as Terapias Alternativas como especialidade e/ ou qualificação do profissional de Enfermagem. In: Conselho Regional de Enfermagem de São Paulo (COREN-SP). Documentos básicos de enfermagem: enfermeiros, técnicos, auxiliares. São Paulo; 2001. p.159-60.

12. Sousa FF, Silva JA. A métrica da dor (dormetria): problemas teóricos e metodológicos. Rev Dor. 2005;6(1):469-513.

13. Conselho Federal de Enfermagem (COFEN); Departamento de Tecnologia da Informação. Análise de dados dos profissionais de enfermagem existentes nos Conselhos Regionais [Internet]. Brasília; 2011[citado 2013 maio 10]. Disponível em: http://site.portalcofen.gov.br/sites.default/ files/pesquisaprofissionais.pdf

14. Coelho ACVD, Ramos ICA, Sumaya S, Braga VAB, Coelho PBB. Técnico de Enfermagem e o cuidado da sua saúde: conhecendo esta realidade. Ciênc Cuid Saúde. 2010;9(3):487-93.

15. World Health Organization. Obesity: preventing and managing the Global epidemic. Report of a World Health Organization Consultation. Geneva; 2000.

16. Melo CF, Munari DB, Silva AP, Brasil VV. Revisão integrativa acerca do trabalho de Enfermagem em unidades de urgência e emergência. Cuid Arte Enferm. 2011;5(1):52-61.

17. Alves Neto O, Costa CMC, Siqueira JT, Teixeira MJ. Dor: princípios e prática. Porto Alegre: Artmed; 2009.

18. Xu M, Yan S, Yin X, Li X, Gao S, Han R, Wei L, et al. Acupuncture for chronic low back pain in long-term follow-up: a metaanalysis of 13 randomized controlled trials. Am J Chin Med. 2013;41(1):1-19.

19. Furlan AD, Yazdi F, Tsertsvadze A, Gross A, Tulder MV, Santaguida $L$, et al. A systematic review and meta-analysis of efficacy, cost-effectiveness, and safety of selected complementary and alternative medicine for neck and lowback pain. Evid Based Complement Alternat Med [Internet]. 2012 [cited 2012 May 10]. Available from: http://www.ncbi. nlm.nih.gov/pmc/articles/PMC3236015/
20. Silva CD, Ferraz GC, Souza LAF, Cruz LVS, Stival MM, Pereira LV. Prevalência de dor crônica em estudantes universitários de Enfermagem. Texto Contexto Enferm. 2011:20(3):519-25.

21. Guerra CSOMP. Prevalência de lombalgias nos enfermeiros [dissertação]. Viseu (PT): Instituto Politécnico de Viseu, Escola Superior de Saúde de Viseu; 2011.

22. Magnago TSBS, Lisboa MTL, Souza IEO, Moreira MC. Musculoskeletal disorders in nursing workers: evidences associated to work conditions. Rev Bras Enferm. 2007;60(6):701-5.

23. Gonçalves JRS, Melo EP, Lombas SRL, Mariano CS, Barbosa L, Chillida MSP. Causas de afastamento entre trabalhadores de enfermagem de um hospital público do interior de São Paulo. Rev Min Enferm. 2005;9(4):309-14.

24. Cho YJ, Song YK, Cha YY, Shin BC, Shin IH, Park HJ. Acupuncture for chronic low back pain: a multicenter, randomized, patient-assessor blind, sham-controlled clinical trial. Spine. 2013;38(7):549-57.

25. Gordon A, Callaghan D, Spink D, Cloutier C, Dzongowski P, O'Mahony W, et al. Buprenorphine transdermal system in adults with chronic low back pain: a randomized, doubleblind, placebo-controlled crossover study, followed by an open-label extension phase. Clin Ther. 2010;32(5):844-60.

26. Prado JM, Kurebayashi LFS, Silva MJP. Auriculotherapy effectiveness in the reduction of anxiety in nursing students. Rev Esc Enferm USP [Internet]. 2012 [cited 2013 May 12];46(5):1200-6. Available from: http://www.scielo.br/pdf/ reeusp/v46n5/en_23.pdf

27. Castro-Sánchez AM, Matarán-Peñarrocha GA, GraneroMolina J, Aguilera-Manrique G, Quesada-Rubio JM, MorenoLorenzo C. Benefits of massage-myofascial release therapy on pain, anxiety, quality of sleep, depression, and quality of life in patients with fibromyalgia. Evid Based Complement Alternat Med [Internet]. 2011 [cited 2012 May 10]. Available from: http://www.ncbi.nlm.nih.gov/pmc/articles/ PMC3018656/

28. Irnic D, Behrens N, Molzen H, König A, Gleditsch J, Krauss $M$, et al. Randomised trial of acupuncture compared with conventional massage and sham laser acupuncture for treatment of chronic neck pain. BMJ. 2001;322(7302):1574-8.

29. Lelis CM, Battaus MRB, Freitas FCT, Rocha FLR, Marziale MHP, Robazzi MLCC. Distúrbios osteomusculares relacionados ao trabalho em profissionais de Enfermagem: revisão integrativa da literatura. Acta Paul Enferm. 2012;25(3):477-82.

30. Tinubu BM, Mbada CE, Oyeyemi AL, Fabunmi AA. Workrelated musculoskeletal disorders among nurses in Ibadan, South-west Nigeria: a cross-sectional survey. BMC Musculoskelet Disord. 2010;11:12..
Correspondence addressed to: Talita Pavarini Borges Av. Dr. Enéas de Carvalho Aguiar, 419 - Cerqueira César CEP 05403-000 - São Paulo, SP, Brazil E-mail: talita_pavarini@yahoo.com.br 